\title{
Fixed Term Work Agreement in Law No.: 11/2020 Concerning Job Creation : A Juridical Analysis
}

\author{
Yoshi Erlina, Ramlani Lina Sinaulan \\ Program Magister Ilmu Hukum, Universitas Jayabaya \\ dr.ramlanisinaulan@gmail.com
}

Received: 12 Januari 2021; Revised: 26 Februari 2021; Accepted: 28 April 2021

DOI: http://dx.doi.org/10.37905/aksara.7.2.395-404.2021

\begin{abstract}
Abstrak
Pusat perhatian dalam penelitian ini adalah pengaturan tentang pengaturan tentang perjanjian kerja waktu tertentu (PKWT) dalam UU No.: 13/2003 tentang Ketenagakerjaan dan UU No.: 11/2020 tentang Cipta Kerja. Tema ini menarik untuk diteliti untuk mengetahui sejauhmana UU No.: 11/2020 tentang Cipta Kerja, ---produk legislasi dengan metode omnibus law yang pertama di Indonesia---, memberikan perlindungan hukum yang lebih baik kepada kaum pekerja (buruh) dibandingkan dengan UU No.: 13/2003. Asumsinya adalah bahwa adanya pengaturan dan pembatasan yang jelas tentang penggunaan PKWTT, kita dapat mengetahui sejauhmana hak-hak pekerja mendapat perlindungan yang memadai dalam suatu sistem hukum dalam berhadapan dengan hak-hak majikan (perusahaan). Penelitian ini menggunakan metode penelitian hukum normatif, yakni penelitian hukum yang mencakup: 1). Penelitian terhadap asas-asas hukum; 2). Penelitian terhadap sistematik hukum; 3). Penelitian terhadap taraf sinkronisasi vertikal dan horisontal; 4). Perbandingan hukum; 5). Sejarah hukum. Metode penelitian hukum normatif tersebut dikombinasikan dengan gagasan Lon L. Fuller tentang sistem hukum yang dikenal dengan principles of legality-nya.
\end{abstract}

Kata kunci: perjanjian kerja waktu tertentu (PKWT), perjanjian kerja waktu tidak tertentu (PKWTT), hubungan kerja, omnibus law.

\section{Abstract}

The center of attention in this research is the regulation of the arrangement of a certain time work agreement (PKWT) in Law No.: 13/2003 concerning Manpower and Law No. 11/2020 concerning Job Creation. This theme is interesting to reasearch to find out the extent of Law No.: 11/2020 concerning Job Creation, --legislation products using the first omnibus law method in Indonesia---, provide better legal protection to workers (laborers) than Law No. : 13/2003. The assumption is that there are clear regulations and restrictions on the use of 
PKWTT, we can find out the extent to which workers' rights receive adquate protection in a legal system in dealing with the rights of employers (companies). This research uses normative legal research methods, namely legal research that includes: 1). Research on legal principles; 2). Research on legal systematic; 3). Research on the level of vertical and horizontal synchronization; 4). Comparative law; 5). Legal history.

This normative legal research method is combined with Lon L. Fuller's ideas about the legal system which is known for its principles of legality.

Keywords: fixed time work agreement (PKWT), idenfinite time work agreement, work relationship, omnibus law.

\section{INTRODUCTION}

On 5 October 2020, the Government of the Republic of Indonesia together with the People's Representative Council of the Republic of Indonesia approved the Draft Law on Work Creation to be passed into law. Furthermore, on November 2, 2020 the President of the Republic of Indonesia has ratified it into Law Number 11 of 2020 concerning Job Creation (State Gazette of the Republic of Indonesia of 2020 under number 245, Supplement to the State Gazette of the Republic of Indonesia Number 6573). Thus, is officially in force in the Republic of Indonesia. UU No: $11 / 2020$ is a monumental law, because it simultaneously revises no less than 80 laws. In the literature of legal science, the method of legislation in the formation of Law No: 11/2020 is called the Omnibus law or often referred to as the Omnibus Bill or legislating Omnibus.

Glen S. Krutz (2001) clicking mean Omnibus law Omnibus Bill or Omnibus legislating as: “... the practice of combining numerous measures from Disparate policy areas in one massive bill. "As a method of legislation, the omnibus law was originally recognized in the Anglo-Saxon legal tradition. However, later this method was also used in countries that adhere to the Continental European legal tradition to simplify legislation which is often seen as overlapping. In this case, Indonesia also uses the Omnibus law method in structuring its laws and regulations.

The preamble to Law No $\therefore$ 11/2020 reads: “... that efforts to change regulations relating to the convenience, protection and empowerment of cooperatives and micro, small and medium enterprises, enhancing the investment ecosystem, and accelerating national strategic projects, including improving the protection and welfare of workers done through changes in the Act sectors that do not support the establishment of synchronization to ensure the acceleration of copyrighted work, so that the necessary legal breakthrough that can solve various problems in some Act into the Act is comprehensive. "From the sound of the preamble, we can see that the synchronization of legislation through the omnibus 
law method is aimed at ensuring increased investment in Indonesia in order to create the widest possible job opportunities. One of the laws revised by Law No.: 11/2020 is Law Number 13 of 2003 concerning Manpower. It is no secret that Law No.: $13 / 2003$ is seen as a legal product that sided with workers or workers. Entrepreneurs often complain about this law as a legal product that does not favor the creation of a business climate in Indonesia. The extent to which such an assessment of UU No.: $13 / 2003$ contains the truth is an interesting subject to research.

This paper will focus on the arrangement of a certain time work agreement in Law No.: 11/2020. As is well known, seen from the validity period of the work agreement, Article 56 paragraph (1) of Law No.: 13/2003 distinguishes between two types of work agreements, namely a work agreement for a certain period of time and a work agreement for an indefinite period of tim. A certain time work agreement is a work agreement that states explicitly when the work agreement will end. Meanwhile, an indefinite work agreemen) is a work agreement that does not explicitly state the validity period. A fixed-time work agreement is commonly referred to as a work agreement for temporary workers, while an indefinite work agreement is referred to as an agreement for permanent workers.

Article 56 paragraph (2) of Law No.: 13/2003 states that PKWT is based on: a. a period of time, or b. completion of a certain job. This means that a work agreement for a certain period of time will expire because: a. The term of validity of the agreement has indeed ended, or the work which is the object of the work agreement has been completed. In labor law, the differentiation of PKWT from PKWTT is considered important because it involves the rights and obligations of the parties at the termination of the employment relationship in the work agreement. For example, in Law N : 13/2003, the termination of a work relationship that is bound with a PKWT does not require permission from the local manpower office, while termination of a work relationship that is bound with a PKWTT requires permission from the local manpower office. Termination of work relations tied to PKWT is not accompanied by severance pay, while termination of work relations tied to PKWTT must be accompanied by payment of severance pay.

\section{METHOD}

Posts have to use methods an normative law. Soekanto and Mamudji (1985) define the normative legal research method as legal research which is carried out by examining library materials or mere secondary data. Furthermore Soekanto and Mamudji argued that normative legal research includes: 1). Research on legal principles; 2). Research on legal systematic; 3). Research on the level of vertical and horizontal synchronization; 4). Comparative law; 5). Legal history. This paper will focus more on the first three things that are the scope of normative legal research methods, namely research on legal principles, research on legal systematic, 
and research on the level of vertical and horizontal synchronization. The last two things, namely research on comparative law and research on legal history will not be the center of attention of this paper. The reason for choosing the scope of this research is purely a pragmatic consideration, namely the lack of available time and the ability of the author to include research on comparative law and research on legal history into this paper.

The research findings using the normative legal research method as intended by Soekanto and Mamudji mentioned above will be tried to understand in the perspective of the legal system developed by Lon L. Fuller. However, first, the understanding of the system will be limited as a complex unit, consisting of parts that are interconnected with one another, where the parts work together actively to achieve the main objectives of the unity. According to William A. Shrode and Voich as quoted by Rahardjo (1991), the basic notions contained in the system are:

1. Goal-oriented systems;

2. The whole is more than the sum of its parts;

3. A system interacts with a larger system, namely its environment;

4. The working of the parts of the system creates something of value;

5. Each part must match each other;

6. There is a unifying force that binds the system.

In the framework of understanding the system above, to find out whether we are dealing with a legal system or not, Lon L. Fuller (1969) introduced eight principles which he called the principles of legality, namely:

1. A legal system must contain regulations, it is not enough to only contain decisions that are ad hoc in nature;

2. These regulations must be announced;

3. There should be no retroactive regulations;

4. The rules must be arranged in an understandable formula;

5. A legal system must not contain conflicting regulations;

6. The regulations must not contain more demands than what is practicable;

7. There should be no habit of changing the rules so often that a person will lose orientation;

8. There must be a match between the promulgated regulations and their day-today implementation.

Furthermore, Lon L. Fuller stated that the eight principles mentioned above are not just a requirement for the existence of a legal system, but also a measure of the level of morality contained in a legal system. 


\section{RESULTS AND DISCUSSION}

Article 1 number 15 Law No $\therefore$ 13/2003 defines a work relationship as a relationship between an entrepreneur and a worker / laborer based on a work agreement, which has elements of work, wages and orders. Soepomo (1970), during his lifetime was a professor of labor law who was quite authoritative in Indonesia, giving a more or less the same formula regarding work relations, namely: “... the relationship between a worker and an employer occurs after an agreement is made by the worker and the employer, where the worker declares his ability to work for the employer by receiving wages and where the employer declares his ability to employ workers by paying wages. "From the above formulation it can be said that the essence of a work relationship or the element that distinguishes a work relationship from other legal relationships is the existence of work owned by the company (the employer), the worker does the work under orders, and as a counterpart to the work performance of the worker. receive wages from the company (employer). The "under command" element in the employment relationship in fact places the worker (laborer) in a relatively weak position in dealing with the employer throughout the implementation of the work agreement. This means that an equal position between the parties at the negotiation stage of the work relationship automatically becomes a superior-subordinate relationship as soon as an agreement is reached between the parties to bind themselves to a working relationship, in which the worker (laborer) is on the side that relatively weak because it is under the orders of the employer.

The element of "under orders" which is one of the essences of labor relations results in a working relationship that cannot be equated with other legal relations in which the parties are in a position that is juridically equal to the extent of the implementation of the legal relationship concerned. The element of "under orders" in employment relations is the reason for the presence of the state in labor issues which are then referred to as industrial relations. Article 1 point 16 of Law No .: 13/2003 relations as: "... a system of relationships formed between the actors in the process of production of goods and / or services that consist of elements from employers, workers / laborers and the government which is based on the values of Pancasila and the 1945 Constitution of the Republic of Indonesia . "In other words, the presence of the state cq the government in the relationship between workers and employers is needed in order to protect workers (workers) who have a relatively weak position vis-à-vis the employer (entrepreneur). More emphatically, Prof. Imam Soepomo stated that the main objective of labor law is the implementation of social justice in labor and this implementation is carried out by protecting workers against the unlimited power of the employer. 
In the context of the definition of security stated above, the state cq the government is present in the relationship between the worker (laborer) and the employer (entrepreneur), not only at the time of carrying out the work relationship, but also since the formulation of the employment relationship. Article 52 paragraph (1) of Law No.: 13/2003 does state that work agreements are made on the basis of the agreement of both parties. However, Article 54 paragraph (1) regulates matters that at least are contained in a work agreement, namely: a. name, company address and type of business; b. name, gender, age and address of the worker / laborer; c. position or type of work; d. place of work; e. the amount of wages and the method of payment; f. working conditions that state the rights and obligations of the entrepreneur and worker / laborer; g. starting and the period of validity of the work agreement ; h. the place and date the work agreement was made; and i. signatures of the parties in the work agreement. From the formulation of the provisions of Article 54 paragraph (1) of Law No.: 13/2003 mentioned above, it can be seen that the clause on "the start and period of the work agreement " is a matter that must be included in every work agreement. It is reasonable to assume that this clause is required in every work agreement in order to realize the principle of legal certainty in employment relationships .

Article 56 paragraph (1) of Law No .: 13/2003 states a labor agreement made for a certain time or for an unspecified time . Furthermore, Article 56 paragraph (2) states that the work agreement for a certain time as referred to in paragraph (1) is based on: a. time period; or b. completion of certain jobs. This means that the period of implementation of a work agreement can be based on a period that was agreed upon from the start, it could also be because the work being the object of the work agreement has been completed. Article 57 paragraph (1) states a PKWT made in writing and should be in Indonesian and Latin letters. At this point we see how Law No.$: 13 / 2003$ protects workers by requiring that the employment relationship be bound in the form of a written agreement using Indonesian and complete letters . In other words, the work agreement must be made in a language and writing that can be easily read and understood by employees. Furthermore, Article 57 paragraph (2) states when an employment agreement for a certain period of time made it not written, then the employment agreement is automatically considered as PKWTT .

According to Law No .: 13/2003, not every job can be tied to an PKWT. The provisions of Article 59 paragraph (1) clearly state that PKWT can only be made for: a. a one-time job or a temporary one; $b$. work which is estimated to be completed in the not too long period of time and a maximum of 3 (three) years; c. work that is seasonal in nature; or d. work related to new products, new activities, or additional products that are still in trial or investigation. The mention in Article 59 paragraph (1) above is limitative. This means that it is not permissible to add to what has been explicitly stated in Article 59 paragraph (1). Furthermore, Article 59 
paragraph (4) states: “ A work agreement for a certain period of time can be made for a maximum of 2 (two) years and may only be extended 1 (one) time for a maximum period of 1 (one) year. "What is very interesting is the provision of Article 59 paragraph (7) which reads:" A work agreement for a certain period of time that does not meet the provisions referred to in paragraph (1), paragraph (2), paragraph (4), paragraph (5) and paragraph (6) then by law it becomes a working agreement for an indefinite period of time . " [Author added in bold print].

As stated in the previous section, that the working relationship that is bound with PKWTT, based on Article 151 paragraph (3) of Law No .: 13/2003, requires prior approval from the industrial relations dispute settlement agency . In addition, the termination of the employment relationship tied to the PKWTT must be accompanied by payment of severance pay and / or service pay and compensation from the employer to the worker (worker). As stipulated in Article 156 of Law No.: $13 / 2003$, severance pay and / or service pay and compensation from employers to workers (workers) depend on the length of service the worker has served.

From the description above, it can be seen that workers are indeed more profitable if their work relationship with their employer is tied to an PKWTT. The benefits obtained by workers if the work relationship is bound by an unspecified work agreement is freedom from unilateral and arbitrary termination of employment by the employer as well as obtaining financial benefits in the form of severance pay and / or service pay and compensation money in the event of termination of employment.

According to the provisions of Article 81 of Law No.: 11/2020, several provisions in Law No .: 13/2003 are amended. Based on Article 81 point 15 of Law No.: 11/2020, the provisions in Article 59 paragraph (1) of Law No .: 13/2003 are as follows: " A work agreement for a certain period of time can only be made for certain jobs which according to the type and nature or work activities will be completed within a certain time, namely as follows:

1. a one-time job or a temporary one;

2. work which is estimated to be completed in the not too long time;

3. work that is seasonal in nature;

4. work related to new products, new activities, or additional products that are still in trial or investigation; or

5. work of which type and nature or activity are not permanent. "[Boldface from author].

The Explanation section states: "The work agreement in this paragraph is registered at the agency responsible for manpower affairs." When compared with the formulation in Article 59 paragraph (1) of Law No.: 13/2003, the formula in Article 81 of Law No .: 11/2020 has the phrase " and a maximum of 3 (three) years. 
"Is abolished in such a way that item b in full becomes:" work which is estimated to be completed in not too long time "Grammatically, perhaps these changes are not too principal. However, the legal implications do not appear to be simple.

Now the formulation in Article 81 point 15 of Law No.: 11/2020, in which the provisions of Article 59 paragraph (1) letter b of Law No.: 13/2003 become: "work which is estimated to be completed in not too long time ", without a phrase "A maximum of 3 (three) years" opens the potential for subjective interpretation of the longest time limit in interpreting the phrase "not too long time "Not too long for person A, it could be too long for person B. Not too long for the employer, it could be too long for the worker and vice versa. In the formulation of Article 81 point 15 of Law No.: 11/2020, Article 59 paragraph (4) of Law No.: 13/2003 is amended to: "Further provisions regarding the type and nature or activity of work, period of time, and deadline for extension of the agreement. certain working hours are regulated in a Government Regulation “. Previously, Article 59 paragraph (4) reads: "A work agreement for a specified period of time can be held for a maximum of 2 (two) years and may only be extended 1 (one) time for a maximum period of 1 (one). year. "In other words, the limitation on the extension of PKWT in Law No.: $11 / 2020$ has been removed by the provisions of Article 81 point 15 . Likewise the provisions of Article 59 paragraph (7) in Law No.: 13/2003 which reads: "A work agreement for a certain period of time that does not fulfill the provisions referred to in paragraph (1), paragraph (2), paragraph (4), paragraph (5) and paragraph (6) then for the sake of the law it becomes a working agreement for an indefinite period of time. "Has been abolished by the provisions of Article 81 point 15 of Law No.: $11 / 2020$. Teleologically, the formulation in Article 59 paragraph (1) letter b of Law No.: 13/2003 which reads: "Work which is estimated to be completed in not too long and at most 3 (three) years" as well as Article 59 paragraph (7) which reads: "A work agreement for a specified period of time that does not meet the provisions as referred to in paragraph (1), paragraph (2), paragraph (4), paragraph (5) and paragraph (6), by law it becomes an indefinite work agreement. "It is intended that the period of validity of a PKWT is not prolonged and is not used for all types and characteristics of work. This means that the formulation of Article 59 of Law No.: $13 / 2003$ is filled with provisions aimed at making PKWT enforceable to be limitative, both in terms of duration and in terms of type of work. As mentioned in the previous section, the interests of workers (workers) will benefit more if the work relationship is tied to an PKWTT. From the description above, it can be said that the regulation on PKW T in labor law, in this case the labor law, is intended so that the PKWT is not prolonged and is not used for any type of work. The basic assumption is that the state, through legislation, needs to be present in the relationship between workers and employers, because this relationship is characterized by inequality, in which workers (laborers) are in a weaker position. 
At this point we see how the provisions regarding PKWT in Article 81 point 15 of Law No.: 11/2020 contradict the principles of legality put forward by Lon L. Fuller, especially in this case the 5th principle, namely: "A legal system does not may contain conflicting regulations ". The basic principle of labor law is that the state needs to be present in the relationship between workers and employers in order to uphold justice in an unequal relationship, where workers are in a weaker position. Likewise, the basic principle of regulating non- permanent contracts (PKWT) is to prevent non- permanent contracts from being used for every type of work and is enforced without time limits. However, the basic principles seem to have been completely ignored by $\mathrm{P}$ of 81 point 15 of Law No.: 11/2020.

Regarding the principles of legality he put forward, Lon L. Fuller further states that the eight principles mentioned above are not only requirements for the existence of a legal system, but also a measure of the level of morality contained in a legal system.

\section{CONCLUSION}

From the description above, it is possible to draw the main points of thought that apply as a conclusion from the discussion throughout this paper as follows.

1. The regulation on PKWT in $\mathrm{P}$ origin 81 point 15 No.: 11/2020 undergoes significant changes when compared to the regulation on PKWT in Article 59 of Law No.: 13/2003;

2. The regulation on PKWT in Article 59 of Law No.: 13/2003 is formulated in such a way that the PKWT applies in a limited manner, both in terms of its validity period and in terms of the types of work that can be agreed with the PKWT;

3. The regulation on PKWT in P origin 81 point 15 of Law No.: 11/2020 has the potential to perpetuate the validity of PKWT and is open to be used for any type of work.

\section{REFERENCES}

Fuller, L. L. (1969). The Morality of Law. Conn: Yale University Press.

Kemenperin.go.id. (2003). "Undang-Undang Republik Indonesia No. 13 Tahun 2003". Undang-Undang(1), 1-34. Retrieved from http://www.kemenperin.go.id/kompetensi/ UU_13_2003.pdf

Krutz, G. S. (2001). Hitching a Ride: Omnibus Legislating in The U.S. Congress. Colombus: Ohio State University Press.

Rahardjo, S. (1991). Ilmu Hukum. Bandung: Citra Aditya Bhakti.

Soekanto, S., \& Mamudji, S. (1985). Penelitian Hukum Normatif: Suatu Tinjauan Singkat. Jakarta: Rajawali Press.

Soepomo, I. (1970). Pengantar Hukum Perburuhan. Jakarta: Djambatan. 
Yuhelson, Sinaulan, R. L., \& Rahmat, A. (2020). "Perlindungan Sosial bagi Perempuan Korban Pernikahan Dini di Gorontalo". Jurnal Pemberdayaan Masyarakat: Media Pemikiran dan Dakwah Pembangunan, 4(1). doi:10.14421/jpm.2020.041-10 